\title{
Zobowiązanie podatkowe
}

\section{w podatku od towarów i usług}

- analiza na tle przepisów

ogólnego prawa podatkowego

\section{Tax liability in tax on goods and services \\ - analysis against the background \\ of general tax law}

Streszczenie. $\mathrm{W}$ ramach artykułu dowiedziono, że zobowiązanie podatkowe w podatku od towarów i usług powstaje wraz z końcem okresu rozliczeniowego, zaś przyjęty model powstawania powinności podatkowej odpowiada koncepcji formalnego wyboru podatkowego. Może on zostać dokonany również po upływie terminu płatności podatku aż do doręczenia decyzji podatkowej. Wydając tę decyzję, organ podatkowy powinien przypisać podatek naliczony do najwcześniejszego okresu, w którym odliczenie stało się prawnie możliwe.

Słowa kluczowe: podatek od towarów i usług; zobowiązanie podatkowe; podatek naliczony; podatek należny. 


\begin{abstract}
In this article it has been proved that a tax liability in tax on goods and services arises at the end of the settlement period and that implemented tax liability model corresponds to the concept of formal tax choice. It can also be made after the expiry of the tax payment deadline, up to the delivery of the tax decision. When issuing decision, the tax authority should assign input tax to the earliest period in which deduction became legally possible.
\end{abstract}

Keywords: tax on goods and services; tax liability; input tax; output vat.

\title{
1. Wprowadzenie
}

Nie będzie przesadą stwierdzenie, że pojęcie zobowiązania podatkowego to kluczowa kategoria w dziedzinie ogólnego prawa podatkowego. Stanowi ona swego rodzaju zwieńczenie procesu konstytuowania się powinności zapłaty podatku na rzecz związku publicznoprawnego. Wraz z powstaniem zobowiązania podatkowego powinność ta - zgodnie z jej normatywną definicją określoną w art. 5 ustawy z dnia 29 sierpnia 1997 r. Ordynacja podatkowa ${ }^{1}$ - zostaje skonkretyzowana m.in. co do kwoty oraz terminu zapłaty.

Nie można jednak stracić z pola widzenia, że sposób, w jaki powstaje zobowiązanie podatkowe, nie jest jednakowy na gruncie wszystkich ustaw podatkowych. Jest to stwierdzenie o tyle oczywiste, że charakter ${ }^{2}$ oraz zasady ogólne ${ }^{3}$ dotyczące poszczególnych podatków istotnie się od siebie różnią. Katalog przesłanek, których realizacja warunkuje powstanie

1 Ustawa z dnia 29 sierpnia 1997 r. Ordynacja podatkowa (tekst jedn. Dz.U. z 2019 poz. 900), dalej: o.p.

2 Na przykład podział na podatki bezpośrednie i pośrednie. Zob. A. Gomułowicz, Klasyfikacja podatków [w:] A. Gomułowicz, J. Małecki, Podatki i prawo podatkowe, Warszawa 2006, LEX/wersja elektroniczna.

3 Mimo pośredniego charakteru podatku od towarów i usług oraz podatku akcyzowego ten pierwszy cechuje wielofazowość. Z kolei w podatku akcyzowym zasadą jest jednofazowość. Zob. A. Bącal, D. Dominik, M. Militz, P. Ogiński, Zasady dotyczq̨e podatku od towarów i usług, „Przegląd Podatkowy” 2009, nr 11, s. 2; A. Mudrecki, Opodatkowanie olejów smarowych w świetle orzecznictwa Naczelnego Sqqu Administracyjnego i Trybunału Sprawiedliwości Unii Europejskiej [w:] T. Nowak, P. Stanisławiszyn (red.) Prawo celne i podatek akcyzowy. Blaski i cienie dziesięciu lat członkostwa Polski w Unii Europejskiej, Warszawa 2016, LEX/wersja elektroniczna. 
zobowiązania podatkowego, będzie więc każdorazowo usytuowany w normach ustawy regulującej opodatkowanie danym podatkiem.

Tak zarysowane tło wyznacza katalog problemów badawczych będących przedmiotem analizy $\mathrm{w}$ ramach niniejszego artykułu. Pierwszym $\mathrm{z}$ nich jest rozstrzygnięcie występującego w literaturze oraz orzecznictwie sporu dotyczącego momentu powstania zobowiązania podatkowego w podatku od towarów i usług. Przesądzenie tej kwestii będzie wymagało starannej analizy charakteru zobowiązania podatkowego w tym podatku, w tym odniesienia się do aprobowanej w doktrynie koncepcji podatkowego stanu faktycznego oraz występujących w ogólnym prawie podatkowym definicji obowiązku oraz zobowiązania podatkowego. Poczynione ustalenia będą z kolei stanowić bazę dla rozstrzygnięcia dwóch dodatkowych zagadnień. Są nimi mianowicie kwestia wysokości zobowiązania podatkowego w przypadku opóźnienia w złożeniu deklaracji podatkowej (zapłacie podatku), a także zasady określenia zobowiązania podatkowego przez organ podatkowy w ramach postępowania podatkowego.

\section{Rola podatkowego stanu faktycznego w kształtowaniu powinności podatkowych}

Punktem wyjścia dla dalszych rozważań należy uczynić prezentowaną w nauce teorię podatkowego stanu faktycznego. Można zdefiniować go jako katalog przesłanek faktycznych i prawnych, których spełnienie skutkuje powstaniem skonkretyzowanej powinności podatkowej. Jak się wydaje, taki właśnie sens nadają mu przedstawiciele doktryny. Tytułem przykładu, A. Kostecki wskazywał, że podatkowy stan faktyczny stanowi zbiór przesłanek usytuowanych w hipotezie normy podatkowoprawnej, których realizacja prowadzi do powstania obowiązku podatkowego, a w konsekwencji determinuje również wysokość zobowiązania podatkowego ${ }^{4}$. A. Nita - bazując na ustaleniach nauki niemieckiej - określa

4 A. Kostecki, Podatkowy stan faktyczny [w:] M. Mazurkiewicz (red.), Studia z zakresu polityki finansowej i prawa finansowego, Wrocław 1992, s. 134. Na usytuowanie podatkowego stanu faktycznego w hipotezie normy podatkowoprawnej wskazywał także 
z kolei podatkowy stan faktyczny jako „(...) ogół abstrakcyjnych przesłanek zawartych materialnoprawnej normie prawnopodatkowej, których urzeczywistnienie wywołuje określone skutki prawne”5. Autor ten zwraca ponadto uwagę, że pojęciu temu można nadać wąskie oraz szerokie znacznie. W pierwszym przypadku podatkowy stan faktyczny może być utożsamiany z przedmiotem opodatkowania. W drugim zaś z ogółem przesłanek, których realizacja powoduje powstanie stosunku podatkowoprawnego $^{6}$. Zdaniem R. Mastalskiego jest to natomiast ogół znamion stanu faktycznego, których spełnienie wywołuje określone skutki prawne na niwie prawa podatkowego ${ }^{7}$. C. Kosikowski określił z kolei podatkowy stan faktyczny jako przedmiot podatku, tj. „(...) stan faktyczny (zachowanie lub zdarzenie), z którym ustawa łączy powstanie, zmianę lub ustanie obowiązku podatkowego ${ }^{8}$,

W literaturze ${ }^{9}$ wyróżnia się otwarte i zamknięte podatkowe stany faktyczne. W przypadku otwartych podatkowych stanów faktycznych opodatkowaniu podlegają zjawiska występujące w pewnym przedziale czasu. Przykładem takiej konstrukcji prawnej jest opodatkowanie dochodu osiąganego w ciągu roku podatkowego. Wówczas obowiązek podatkowy powstaje wraz z początkiem okresu podlegającego rozliczeniu (początek roku podatkowego), zaś zobowiązanie podatkowe wraz z zakończeniem owego okresu (koniec roku podatkowego). Charakterystyczną cechą ukształtowania podatkowego stanu faktycznego w taki sposób będzie więc okoliczność, że obowiązek podatkowy oraz zobowiązanie podatkowe

I. Korczyński. Zob. I. Korczyński, Podatkowoprawny stan faktyczny [w:] B. Brzeziński (red.) Prawo podatkowe. Teoria. Instytucje. Funkcjonowanie, Toruń 2009, s. 30.

5 A. Nita, Stosunek prawnopodatkowy. Obowiqzek podatkowy i zobowiqzanie podatkowe, Kraków 1999, s. 17-18.

6 Tamże, s. 18. A. Nita opowiada się za szerokim ujęciem podatkowego stanu faktycznego. R. Mastalski, Wprowadzenie do prawa podatkowego, Warszawa 1995, s. 57-58.

8 C. Kosikowski, Pojęcie i cechy ustawy podatkowej w Polsce [w:] C. Kosikowski, Ustawa podatkowa. Geneza, ewolucja i stan prawny; tworzenie; kontrola; wykładnia; wykonywanie, Warszawa 2006, LEX/wersja elektroniczna.

$9 \quad$ R. Mastalski, Prawo podatkowe, Warszawa 2014, s. 205; R. Mastalski, Glosa do wyroku SN z dnia 18 maja 2001 r., III RN 95/00, „Orzecznictwo Sądów Polskich”, pkt 5, akapit 2, LEX/wersja elektroniczna; M. Niezgódka-Medek, Komentarz do art. 5 Ordynacji podatkowej [w:] S. Babiarz, B. Dauter, R. Hauser, A. Kabat, M. Niezgódka-Medek, J. Rudowski, Ordynacja podatkowa. Komentarz, Warszawa 2019, s. 92. 
powstają w różnych momentach. Odmiennie sytuacja przedstawia się w przypadku podatków charakteryzujących się zamkniętym podatkowym stanem faktycznym. Obowiązek i zobowiązanie podatkowe powstają wówczas w tym samym momencie.

Istotny wpływ na normatywny kształt podatkowego stanu faktycznego wywiera także instytucja opcji podatkowych (wyboru podatkowego). Polega ona na tym, że dane zdarzenie może wywołać dwa lub więcej odmiennych skutków prawnych, zaś wybór określonego skutku pozostaje w gestii podmiotu zobowiązanego z tytułu podatku. W związku z tym można mówić wówczas o wariantowej konstrukcji podatkowego stanu faktycznego, albowiem podatnik jest uprawiony wybrać jedną z jego „zaproponowanych” przez ustawodawcę - wersji ${ }^{10}$. Należy przy tym zauważyć, że opcja podatkowa może przybierać dwie formy. Pierwsza z nich, określana mianem materialnego wyboru podatkowego, polega na tym, że podmiot zobowiązany z tytułu podatku wybiera wersję podatkowego stanu faktycznego, którą ma zamiar urzeczywistnić przed lub najpóźniej wraz z rozpoczęciem jego realizacji ${ }^{11}$. Z kolei zgodnie z koncepcją formalnego wyboru podatkowego podatnik podejmuje decyzję już po urzeczywistnieniu podatkowego stanu faktycznego. W takiej sytuacji przedmiotem wyboru jest nie tylko jedna z wersji podatkowego stanu faktycznego zaproponowana przez ustawodawcę, ale i określona postać obowiązku i zobowiązania podatkowego ${ }^{12}$.

Podsumowując rozważania dotyczące podatkowego stanu faktycznego, można postawić tezę, że stanowi on obraz preferencji ustawodawcy, który z zaistnieniem pewnych sytuacji wiąże powstanie skutków podatkowych, natomiast inne zdarzenia pozostawia poza zakresem oddziaływania unormowań podatkowoprawnych. To z kolei oznacza, że wypełnienie wszystkich jego znamion jest warunkiem sine qua non dla ukonstytuowania się zobowiązania podatkowego. Należy więc zaaprobować spostrzeżenie, że jedynym czynnikiem decydującym o powstaniu powinności podat-

10 A. Nita, Porozumienia w prawie podatkowym. Horyzontalne metody determinacji powinności podatkowej, Warszawa 2014, s. 92.

11 Tamże, s. 97.

12 Tamże, s. 98. 
kowej jest realizacja wszystkich elementów podatkowego stanu faktycznego $^{13}$. Przy czym, jak wynika z przywoływanego już art. 5 o.p., skonkretyzowana powinność podatkowa (zobowiązanie podatkowe) wynika z obowiązku podatkowego. Punktem wyjścia dla dalszej analizy należy więc uczynić właśnie ten termin.

\section{Obowiązek podatkowy}

Obowiązek podatkowy nie jest w polskim języku prawnym i prawniczym kategorią nową, lecz posiada dość długą historię. Termin ten pojawił się już w Ordynacji podatkowej z 15 marca 1934 r. ${ }^{14}$ Z kolei Najwyższy Trybunał Administracyjny $w$ jednym ze swoich orzeczeń wskazywał, że „Obowiązkiem podatkowym jest abstrakcyjne zobowiązanie do poniesienia ciężaru podatkowego, związane przez przepis ustawy z zaistnieniem pewnego stanu - faktycznego - w odróżnieniu od zobowiązania podatkowego, będącego już skonkretyzowanym w sposób prawem przepisany i wymagalnym roszczeniem Państwa ${ }^{15}$ ”. Zawierały go również wprowadzone po II wojnie światowej akty prawne dotyczące zobowiązań podatkowych, a mianowicie dekret z 16 maja 1946 r. o zobowiązaniach podatkowych $^{16}$, dekret z dnia 26 października 1950 r. o zobowiązaniach podatkowych $^{17}$ oraz ustawa z dnia 19 grudnia 1980 r. o zobowiązaniach podatkowych $^{18}$. Występuje on również w obecnie obowiązującej o.p. Mimo pojawiających się w nauce głosów postulujących usunięcie tej kon-

\footnotetext{
13 A. Nita, Uchylanie się od opodatkowania jako zjawisko z zakresu prawa karnego i podatkowego [w:] P. Kardas, T. Sroka, W. Wróbel (red.), Państwo prawa i prawo karne. Księga jubileuszowa Profesora Andrzeja Zolla. Tom I, Warszawa 2012, s. 790.

17 Dekret z dnia 26 października 1950 r. o zobowiązaniach podatkowych (Dz.U. 1950 Nr 49, poz. 452).

18 Ustawa z dnia 19 grudnia 1980 r. o zobowiązaniach podatkowych (Dz.U. 1980 Nr 27, poz. 111).
} 
cepcji jurydycznej z ogólnego prawa podatkowego ${ }^{19}$ utrzymanie jej w polskim porządku prawnym zaproponowali również twórcy projektu nowej Ordynacji podatkowej ${ }^{20}$.

Zgodnie z art. 4 o.p. obowiązkiem podatkowym jest wynikająca z ustaw podatkowych nieskonkretyzowana powinność przymusowego świadczenia pieniężnego w związku z zaistnieniem zdarzenia określonego w tych ustawach. W oparciu o tę definicję można wskazać kilka jego właściwości. Po pierwsze, musi mieć on swoje źródło w ustawie. Cecha ta stanowi realizację naukowego i konstytucyjnego postulatu ustawowej regulacji obowiązków w zakresie ponoszenia ciężarów podatkowych ${ }^{21}$. Po drugie, jego przedmiotem jest świadczenie pieniężne. Nie dotyczy on zatem tych stosunków prawnych, które kreowałyby konieczność ponoszenia innych świadczeń, na przykład świadczeń w naturze. Po trzecie, ma on charakter nieskonkretyzowany. Ta właściwość bywa w literaturze poddawana krytyce. Wskazuje się, że powinność per se musi być skonkretyzowana, ponieważ tylko do takiej podmiot zobowiązany jest się w stanie zastosować $^{22}$. Czwarta uwaga dotyczy okoliczności stanowiącej fakt wywoławczy ${ }^{23}$ obowiązku podatkowego. Zgodnie z art. 4 o.p. jest nim zrealizowanie przez podmiot zobowiązany stanu faktycznego określonego w ustawie podatkowej.

19 M. Kalinowski, Kilka uwag dotyczq̨cych posługiwaniem się pojęciem obowiqzek podatkowy w projekcie nowej ordynacji podatkowej, „Przegląd Orzecznictwa Podatkowego" 2018, nr 1, s. 12.

Uzasadnienie do projektu Ordynacji podatkowej, druk sejmowy numer 3517, http://www.sejm.gov.pl/sejm8.nsf/druk.xsp?nr=3517 [dostęp: 29.01 .2020 r.].

21 B. Brzeziński, Wstęp do nauki prawa podatkowego, Toruń 2001, s. 119; B. Brzeziński, Zasady ogólne prawa podatkowego, „Toruński Rocznik Podatkowy” 2015, nr 1, s. 9; M. Kalinowski, Poglady Otto Mayera na prawo i stosunki podatkowe, „Toruński Rocznik Podatkowy” 2015, nr 1, s. 20; R. Mastalski, Prawo podatkowe, Warszawa 2014, s. 57; E. Prejs, Wartości konstytucyjne a prawo podatkowe w orzecznictwie Trybunału Konstytucyjnego [w:] B. Brzeziński (red.) Prawo podatkowe. Teoria. Instytucje. Funkcjonowanie, Toruń 2009, s. 161; Z. Ofiarski, Prawo podatkowe, Warszawa 2008, s. 126.

22 H. Dzwonkowski, M. Dzwonkowski, Komentarz do art. 5 Ordynacji podatkowej [w:] H. Dzwonkowski (red.), Ordynacja podatkowa. Komentarz, Warszawa 2020, Legalis/wersja elektroniczna, teza 23.

23 Pojęcie „faktu wywoławczego” występuje we francuskiej nauce prawa podatkowego. Zob. H. Dzwonkowski, Powstawanie i wymiar zobowiq̨zań podatkowych, Warszawa 2003, s. 44. 


\section{Zobowiązanie podatkowe}

Ukonstytuowany obowiązek podatkowy jest prawną podwaliną dla zobowiązania podatkowego. Jak stanowi bowiem art. 5 o.p., zobowiązaniem podatkowym jest wynikające $\mathrm{z}$ obowiązku podatkowego zobowiązanie podatnika do zapłacenia na rzecz Skarbu Państwa, województwa, powiatu albo gminy podatku w wysokości, w terminie oraz w miejscu określonych w przepisach prawa podatkowego. Zgodnie $\mathrm{z}$ art. $21 \S 1$ pkt 1 o.p. powstaje ono z dniem zaistnienia zdarzenia, z którym ustawa podatkowa wiąże powstanie takiego zobowiązania ${ }^{24}$. Za termin płatności zobowiązania podatkowego - zgodnie $\mathrm{z}$ art. 47 § 3 o.p. - uważa się natomiast ostatni dzień, w którym zgodnie z przepisami prawa podatkowego wpłata powinna nastąpić ${ }^{25}$.

Jak wynika z ustawowej koncepcji kształtowania powinności podatkowych, zobowiązanie podatkowe wynika $\mathrm{z}$ obowiązku podatkowego. Relacja ta została dostrzeżona w literaturze. Przywoływany już R. Mastalski określał ją mianem normatywnego następstwa ${ }^{26}$. Istnienie relacji wynikania „konkretnego stosunku prawnego zobowiązania podatkowego” $\mathrm{z}$ „abstrakcyjnego stosunku obowiązku podatkowego” akcentuje również P. Borszowski ${ }^{27}$. Za interesujący należy uznać pogląd tego autora, że podstawą dla obowiązku podatkowego jest art. 84 Konstytucji Rzeczypospolitej Polskiej ${ }^{28}$, który statuuje zasadę, iż każdy jest obowiązany do ponoszenia ciężarów i świadczeń publicznych, w tym podatków, określonych w ustawie ${ }^{29}$. Z kolei A. Nita podjął się próby ustalenia, w jaki sposób ów

24 W o.p. przewidziano również drugi model kreowania zobowiązań podatkowych, a mianowicie doręczenie decyzji ustalającej zobowiązanie podatkowe. Zob. Art. 21 § 1 pkt 2 o.p.

25 Z kolei w przypadku wydania decyzji ustalającej wysokość zobowiązania termin płatności wynosi 14 dni od daty doręczenia decyzji. Zob. art. 47 § 1 o.p.

26 R. Mastalski, Prawo podatkowe... s. 205; R. Mastalski, Obowiqzek podatkowy i zobowiqzanie podatkowe [w:] M. Weralski (red.), System instytucji prawno-finansowych PRL, Tom III, Instytucje budżetowe, Wrocław 1985, s. 210.

27 P. Borszowski, Elementy stosunku prawnego zobowiq̨zania podatkowego, Kraków 2004, s. 234-235 i 237-238.

28 Konstytucja Rzeczypospolitej Polskiej z dnia 2 kwietnia 1997 r. (Dz.U. z 1997 r. Nr 78, poz. 483).

29 P. Borszowski, Elementy stosunku prawnego..., s. 234. 
dwuetapowy - tj. oparty na konstrukcji obowiązku i wynikającego z niego zobowiązania podatkowego - model kształtowania się powinności podatkowej jest osadzony w koncepcji podatkowego stanu faktycznego. Autor ten opowiedział się za stanowiskiem, iż obowiązek podatkowy stanowi wyraz realizacji podatkowego stanu faktycznego pierwszego stopnia (określanego również mianem podstawowego stanu faktycznego), który determinuje przedmiot oraz podmiot podatku. Natomiast skonkretyzowana powinność podatkowa (zobowiązanie podatkowe) jest rezultatem urzeczywistnienia podatkowego stanu faktycznego drugiego stopnia (wyższego podatkowego stanu faktycznego $)^{30}$. Warto zauważyć, że również na gruncie przedwojennej Ordynacji podatkowej wyróżniano dwa stadia kształtowania się obowiązku poniesienia świadczenia podatkowego na rzecz państwa ${ }^{31}$.

W przeciwieństwie do obowiązku podatkowego zobowiązanie podatkowe to powinność skonkretyzowana ${ }^{32}$. Z przyjętej przez ustawodawcę koncepcji zobowiązania podatkowego wynika bowiem, że w momencie powstania zobowiązania podatkowego przesądzona zostaje jego treść. Dotyczy to w szczególności terminu zapłaty podatku oraz jego wysokości rozumianej jako określona suma pieniężna.

\section{Termin powstania zobowiązania podatkowego w podatku od towarów i usług - prezentacja koncepcji orzeczniczych i doktrynalnych}

W literaturze oraz judykaturze zasadniczo można spotkać się z trzema poglądami dotyczącymi momentu powstania zobowiązania podatkowego w podatku od towarów i usług. Wszystkie one wymagają przedstawienia.

\footnotetext{
30 A. Nita, Porozumienia w prawie podatkowym..., s. 45.

31 S. Rosmarin, Obowiq̨zek podatkowy. Studjum krytyczne w zakresie Ordynacji podatkowej, „Głos Prawa” 1935, nr 3-4, s. 168.

32 Zob. B. Brzeziński, Wstęp do nauki..., s. 131.
} 
Autorzy ${ }^{33}$ aprobujący pierwszą koncepcję wskazują, że podatek od towarów i usług cechuje się zamkniętym podatkowym stanem faktycznym. To z kolei determinuje prawidłowość, że zobowiązanie podatkowe powstaje w tym samym momencie co obowiązek podatkowy (np. w momencie zrealizowania dostawy towarów). Pogląd ten można również spotkać orzecznictwie. Tytułem przykładu, w jednym ze swoich wyroków Naczelny Sąd Administracyjny uznał, że „(...) w przypadku, w którym dochodzi do wykonania odpłatnej usługi, na gruncie podatku od towarów i usług obowiązek podatkowy i zobowiązanie podatkowe powstaną w tym samym momencie, mamy bowiem $\mathrm{w}$ takiej sytuacji do czynienia z zamkniętym stanem faktycznym $(\ldots)^{34 \text { ”. }}$

Zwolennicy drugiego poglądu wskazują, że podatek od towarów i usług to danina rozliczana okresowo, co oznacza, że kwota podatku „(...) może zostać ustalona najwcześniej z upływem okresu rozliczeniowego"35. Podnoszą również, że wpływ na wysokość zobowiązania podatkowego ma nie tylko podatek należny, ale i drugi element konstrukcyjny tej daniny, a mianowicie podatek naliczony ${ }^{36}$. Wskazują przy tym, że kwota podatku naliczonego możliwego do odliczenia jest znana dopie-

33 R. Mastalski, Prawo podatkowe... s. 205; M. Niezgódka-Medek, Komentarz do art. 5 Ordynacji podatkowej [w:] S. Babiarz, B. Dauter, R. Hauser, A. Kabat, M. Niezgódka-Medek, J. Rudowski, Ordynacja podatkowa. Komentarz, Warszawa 2019, s. 92.

34 Wyrok Naczelnego Sądu Administracyjnego z 11 maja 2017 r., I FSK 1386/15. Podobnie wypowiedział się Wojewódzki Sąd Administracyjny w Poznaniu, który uznał, że „(...) zobowiązanie podatkowe w podatku VAT powstaje w tym samym momencie co obowiązek podatkowy w tym podatku”. Zob. Wyrok Wojewódzkiego Sądu Administracyjnego w Poznaniu z 17 października 2012 r., I SA/Po 701/12. Te oraz pozostałe wskazane w kolejnych przypisach wyroki sądów administracyjnych pochodzą z Centralnej Bazy Orzeczeń Sądów Administracyjnych (CBOSA).

35 M. Popławski, Komentarz do art. 5 Ordynacji podatkowej [w:] L. Etel (red.) Ordynacja podatkowa. Komentarz, Warszawa 2017, s. 101. Pogląd ten zdaje się również podzielać A. Bartosiewicz, który dzień zobowiązania podatkowego w podatku od towarów i usług utożsamia z dniem „(...) zamknięcia okresu rozliczeniowego”. Zob. A. Bartosiewicz, Komentarz do art. 99 ustawy o podatku od towarów i usług [w:] A. Bartosiewicz, VAT. Komentarz, Warszawa 2019, LEX/wersja elektroniczna, pkt 53.

36 Spostrzeżenie to jest oczywiście trafne. Na tę okoliczność, tj. wpływ podatku naliczonego na wysokość zobowiązania podatkowego, wskazują także inni autorzy. Zob. T. Michalik, Komentarz do art. 19a ustawy o podatku od towarów i usług [w:] T. Michalik, VAT. Komentarz, Warszawa 2019, Legalis/wersja elektroniczna, pkt 6. 
ro z końcem okresu rozliczeniowego. Powyższe argumenty przesądzają zatem, że podatkowy stan faktyczny w podatku od towarów i usług ma charakter otwarty, co implikuje konkluzję, że podlegająca zapłacie na rzecz organu podatkowego kwota podatku (zobowiązanie podatkowe) zostaje ukształtowana z końcem okresu (miesiąca, kwartału) podlegającego rozliczeniu ${ }^{37}$.

W orzecznictwie można spotkać również trzecią teorią objaśniającą analizowane zagadnienie. Jej zwolennicy zwracają uwagę, że wpływ na wysokość zobowiązania podatkowego ma nie tylko podatek naliczony, co do którego prawo do odliczenia powstało w bieżącym, ale także w poprzednich okresach rozliczeniowych. Jako reprezentatywne dla tego kierunku interpretacyjnego można wskazać stwierdzenie, że zobowiązanie podatkowe kształtuje „(...) wielkość podatku naliczonego wynikającego z faktur (dokumentów celnych) otrzymanych w tymże miesiącu, jak również w miesiącu go poprzedzającym, który nie został rozliczony w miesiącu ich otrzymania" ${ }^{38}$ ". To z kolei powinno prowadzić do wniosku, że skonkretyzowana powinność podatkowa powstaje z upływem terminu rozliczenia (zapłaty) podatku za dany okres, tj. co do zasady do 25. dnia miesiąca następującego po miesiącu, za który ma nastąpić rozliczenie ${ }^{39}$.

37 Wyroki Naczelnego Sądu Administracyjnego z 25 listopada 2009 r., I FSK 1503/08 oraz 14 lutego 2008 r., I FSK 234/07. B. Brzeziński wyartykułował pogląd, że zobowiązanie podatkowe powstaje wraz z końcem okresu rozliczeniowego. Zwrócił jednak uwagę, że - na gruncie obowiązującej poprzednio ustawy - prawo do odliczenia podatku naliczonego może zostać zrealizowane również w kolejnym miesiącu. Zob. B. Brzeziński, Glosa do wyroku składu siedmiu sędziów Naczelnego Sq̨du Administracyjnego z dnia 25 sierpnia 2003 r. (FSA 1/03), „Przegląd Orzecznictwa Podatkowego" 2004, nr 3, s. 229.

38 Wyroki Naczelnego Sądu Administracyjnego z 5 czerwca 2014 r. I FSK 755/13, 10 marca 2009 r., I FSK 75/08, 22 stycznia 2009 r., I FSK 1908/07 oraz wyrok Wojewódzkiego Sądu Administracyjnego w Szczecinie z 26 listopada 2014 r., I SA/Sz 554/14. Choć wskazane wyroki dotyczą nieobowiązującego już stanu prawnego, to przedstawiona w nich argumentacja mogłaby zostać zastosowana również na gruncie obecnego stanu prawnego.

39 Zob. wyroki z poprzedniego przypisu i wyrok Naczelnego Sądu Administracyjnego z 8 sierpnia 2012 r., I FSK 1490/11 oraz wyrok Wojewódzkiego Sądu Administracyjnego w Warszawie z 23 stycznia 2014 r. III SA/Wa 1879/13. 


\section{Uwagi do koncepcji orzeczniczych i doktrynalnych}

Wydaje się, że na aprobatę - choć nie bez kilku zastrzeżeń - zasługuje pogląd, że zobowiązanie podatkowe w podatku od towarów i usług powstaje wraz z końcem okresu rozliczeniowego. Najpierw należy jednak wskazać, dlaczego nie ma dostatecznych racji przemawiających za trafnością pozostałych zapatrywań.

Podstawową wadą koncepcji, zgodnie z którą zobowiązanie podatkowe powstaje $\mathrm{w}$ dacie obowiązku podatkowego, jest pomijanie instytucji podatku naliczonego, która wywiera bezpośredni wpływ na konkretyzację kwoty podatku, który powinien zostać zapłacony na rzecz wierzyciela podatkowego. Gdyby bowiem uznać, że zobowiązanie podatkowe powstaje razem z obowiązkiem podatkowym, to kwotę zobowiązania podatkowego każdorazowo stanowiłby wyłącznie podatek należny. Przykładowo, jeśli w związku z dokonaną dostawą zobowiązanie podatkowe powstawałoby $\mathrm{w}$ momencie zaistnienia obowiązku podatkowego, czyli - zgodnie z art. 19a ust. 1 ustawy z dnia 11 marca 2004 r. o podatku od towarów i usług ${ }^{40}-$ w chwili jej dokonania (na przykład 1. dnia danego miesiąca), to na kwotę zobowiązania podatkowego składałaby się wyłącznie wartość podatku należnego. Tylko jego kwota jest bowiem ponad wszelką wątpliwość znana na moment dokonania dostawy towarów. Jak wiadomo, zgodnie z konstrukcją podatku od towarów i usług konkretną kwotę podatku do zapłaty stanowi jednak różnica pomiędzy podatkiem należnym a podlegającym odliczeniu podatkiem naliczonym. Skoro więc suma podatku naliczonego, który zmniejsza kwotę podatku podlegającego zapłacie, jest znana najwcześniej z upływem okresu rozliczeniowego, to oznacza, że skonkretyzowana powinność podatkowa powstanie nie wcześniej niż $\mathrm{z}$ końcem tego okresu. W związku z tym ten pogląd nie zasługuje na aprobatę.

Kolejna koncepcja sprowadza się do uznania, że skonkretyzowana powinność podatkowa (zobowiązanie podatkowe) powstaje wraz z upły-

40 Ustawa z dnia 11 marca 2004 r. o podatku od towarów i usług (tekst jedn. Dz.U. z 2018 r. poz. 2174). 
wem terminu płatności podatku (złożenia deklaracji), czyli co do zasady z upływem 25. dnia następnego miesiąca. Jak się wydaje, również to zapatrywanie nie jest trafne. Zgodnie z art. 99 ust. 1 i art. 103 ust. 1 u.p.t.u. 25. dzień następnego miesiąca to ostatni dzień na złożenie deklaracji podatkowej i zapłatę podatku. To oznacza, że podatnik może uregulować zobowiązanie podatkowe (złożyć deklarację) za zakończony okres rozliczeniowy w przedziale czasu od 1 . do 25 . dnia następnego miesiąca ${ }^{41}$. Skoro tak, to z prawnego punktu widzenia nie ma żadnych przeszkód, aby podatnik uczynił to wcześniej - np. 10. dnia następnego miesiąca. Nie ma wątpliwości, że taka zapłata stanowi przykład efektywnego wygaśnięcia zobowiązania podatkowego ${ }^{42}$. Gdyby jednak uznać, że zobowiązanie podatkowe powstaje dopiero z 25. dniem następnego miesiąca, to dokonanie zapłaty przed tym dniem (np. 24. dnia), stanowiłoby próbę uregulowania nieistniejącego jeszcze zobowiązania podatkowego. Konsekwencją uznania za trafny tego poglądu musiałaby być konstatacja, iż podatnik może zapłacić podatek wyłącznie 25. dnia następnego miesiąca. Dokonanie tego przed wskazaną wyżej datą, byłoby bowiem tożsame z zapłatą nieistniejącego jeszcze zobowiązania podatkowego, zaś już po jej upływie - z powstaniem zaległości podatkowej.

\section{Kiedy więc powstaje zobowiązanie podatkowe w podatku od towarów i usług?}

Za co do zasady trafną należy uznać koncepcję, zgodnie z którą zobowiązanie podatkowe w podatku od towarów i usług powstaje z końcem danego okresu rozliczeniowego. Pogląd ten wymaga jednak kilku dodatkowych uwag.

Z u.p.t.u. wynika, że podatnik może odliczyć podatek naliczony w deklaracji składanej za okres, w którym w stosunku do nabytych towa-

\footnotetext{
41 Na co wskazuje zawarte w art. 103 ust. 1 u.p.t.u. sformułowanie ustawodawcy, że podatek powinien być zapłacony „(...) w terminie do 25. dnia miesiąca następującego po miesiącu, w którym powstał obowiązek podatkowy (...)” a nie „,...) 25. dnia miesiąca następującego po miesiącu, w którym powstał obowiązek podatkowy (...)”.

Zob. art. $59 \S 1$ pkt 1 o.p.
} 
rów lub usług powstał obowiązek podatkowy oraz otrzymano fakturę (okres podstawowy) lub za dwa kolejne okresy ${ }^{43}$. Decyzja w tym zakresie jest komunikowana organowi podatkowemu po zakończeniu okresu rozliczeniowego podlegającego rozliczeniu - nie powinno mieć to miejsca później niż do 25. dnia następnego miesiąca. To, czy podatek naliczony zostanie odliczony (i) w całości rozliczeniu za okres podstawowy, (ii) częściowo w rozliczeniu za okres podstawowy i częściowo za dwa kolejne okresy, czy też (iii) w całości w rozliczeniu za dwa kolejne okresy, zależy wyłącznie od uznania podatnika. $\mathrm{Z}$ tego wynika, że na koniec okresu rozliczeniowego przepisy prawa nie determinują konkretnej kwoty podatku naliczonego, która może być przypisana tylko do tego okresu, ale określają jedynie jej górną granicę. Ta okoliczność wywiera wpływ na wysokość zobowiązania podatkowego za dany miesiąc. Polega to na tym, że na koniec miesiąca jest znana jedynie jego maksymalna (podatnik nie dokonuje w ogóle odliczenia podatku naliczonego w rozliczeniu za okres podstawowy) i minimalna wysokość (podatnik dokonuje odliczenia całości podatku naliczonego w rozliczeniu za okres podstawowy), jak również warianty pośrednie (podatnik dokonuje odliczenia podatku naliczonego częściowo za okres podstawowy i częściowo w kolejnych okresach).

To prowadzi do konkluzji, że ustawodawca ukształtował sposób powstawania zobowiązania podatkowego w podatku od towarów i usług zgodnie z przywoływaną już koncepcją wariantowej konstrukcji podatkowego stanu faktycznego. Przedmiotem opcji podatkowej (wyboru podatkowego) jest w tym przypadku wysokość podatku naliczonego, który zostanie odliczony za dany okres, a tym samym ukształtuje konkretną postać (wysokość) zobowiązania podatkowego. Wybór ten ma charakter wyboru formalnego, albowiem jest dokonywany już po urzeczywistnieniu podatkowego stanu faktycznego (po zamknięciu okresu podlegającego rozliczeniu).

43 Zob. art. 86 ust. 10, ust. 10 lit. b oraz ust. 11 u.p.t.u. Możliwość odliczenia podatku naliczonego także w kolejnych okresach rozliczeniowych występowała również na gruncie poprzednio obowiązującej ustawy o podatku od towarów i usług. Na tę kwestię zwrócił uwagę B. Brzeziński, który stwierdził, że „(...) podatnik ma prawo do odliczenia podatku naliczonego, nie tylko w tym miesiącu, ale także w miesiącu następnym”. Zob. B. Brzeziński, Glosa do wyroku..., s. 229. 


\section{Niedochowanie terminu na złożenie deklaracji (zapłatę podatku)}

Odrębny problem dotyczy sytuacji, gdy podatnik nie składa deklaracji (i nie płaci podatku) w terminie wskazanym przez ustawodawcę. Powstaje wówczas pytanie, czy decyzja w zakresie wyboru zobowiązania podatkowego w określonej wysokości może nadal zostać podjęta przez podatnika, czy też ustawodawca - wobec braku dochowania terminu - narzuca podatnikowi zobowiązanie podatkowe w ściśle określonej wysokości? Należy zauważyć, że z u.p.t.u. nie sposób wywieść reguły, z której wynikałoby, że w razie niedochowania terminu na złożenie deklaracji podatnik traci prawo do odliczenia podatku naliczonego w jednym z trzech wskazanych przez ustawodawcę okresów. To w konsekwencji oznacza, że w razie złożenia deklaracji (zapłaty podatku) z opóźnieniem podatnik nadal ma prawo do dokonania formalnego wyboru podatkowego w zakresie wymiaru zobowiązania podatkowego. Jak się wydaje, możliwość ta zostanie jednak wyłączona wówczas, gdy podatnikowi zostanie doręczona decyzja określająca wysokość jego zobowiązania podatkowego ${ }^{44}$. Natomiast jest to możliwe w trakcie toczącego się postępowania podatkowego. Należy bowiem podzielić pogląd, że określony w art. 81b § 1 pkt 1 o.p. zakaz obejmuje jedynie korektę złożonej już deklaracji podatkowej, nie zaś deklarację składaną po raz pierwszy. W związku z tym w przypadku złożenia deklaracji po raz pierwszy oraz zapłaty podatku w prawidłowej wysokości wraz z odsetkami za zwłokę w trakcie postępowania podatkowego powinno ono zostać umorzone jako bezprzedmiotowe ${ }^{45}$.

\footnotetext{
44 Oczywiście składanie deklaracji podatkowej i dokonanie zapłaty podatku nie jest również celowe w razie wygaśnięcia zobowiązania podatkowego, np. wskutek przedawnienia. Zob. art. 59 § 1 o.p.

45 L. Etel, Komentarz do art. 81b Ordynacji podatkowej [w:] L. Etel (red.) Ordynacja podatkowa. Komentarz, Warszawa 2017, s. 671.
} 


\section{Decyzja określająca zobowiązanie podatkowe a przypisanie przez organ podatkowy podatku naliczonego do właściwego okresu}

Rozważenia wymagają również zasady określenia przez organ podatkowy zobowiązania podatkowego w sytuacji, gdy podatnik (i) nie złożył deklaracji i nie zapłacił podatku bądź (ii) co prawda złożył deklarację i zapłacił podatek, ale ustalił jego wysokość w nieprawidłowej wysokości, w szczególności nie odliczył podatku naliczonego w ogóle bądź uczynił to w niewłaściwych okresach. W takim przypadku zgodnie z art. $21 \S 3$ o.p. organ podatkowy powinien wydać decyzję określającą wysokość zobowiązania podatkowego w prawidłowej wysokości ${ }^{46}$. Powstaje wówczas pytanie, czy możliwość dokonania wyboru podatkowego jest nadal aktualna, tj. czy podatnik jest władny wskazać organowi, do których okresów rozliczeniowych powinien on $-\mathrm{z}$ zachowaniem terminów wskazanych w art. 86 ust. 10, ust. 10b lit.a i ust. 11 u.p.t.u. - przypisać nieodliczony lub odliczony w niewłaściwym okresie podatek naliczony. Odpowiedź na to pytanie powinna być negatywna. Wynika to z faktu, że wskutek wszczęcia postępowania podatkowego powinność określenia zobowiązania podatkowego w prawidłowej wysokości ciąży na organie podatkowym. Co więcej, przepisy - zarówno ogólnego, jak i szczegółowego - prawa podatkowego nie przewidują wówczas jakiegokolwiek dialogu pomiędzy organem podatkowym a podatnikiem. Powstaje jednak pytanie, czy organ podatkowy posiada swobodę w przypisaniu kwot podatku naliczonego do poszczególnych - wskazanych w art. 86 ust. 10, ust. 10b pkt 1 oraz ust. 11 u.p.t.u. - okresów rozliczeniowych. Jak się wydaje, należy uznać, że organ podatkowy powinien przypisać podatek naliczony z uwzględnieniem zasad ogólnych rządzących tą daniną, w szczególności z poszanowaniem zasady neutralności podatkowej. Wynika z niej, że podmiot prowadzący działalność gospodarczą nie powinien ponosić ciężaru podatku od warto-

46 Z przepisem tym jest skorelowany art. 21 § 3a o.p. Na jego podstawie organ podatkowy jest uprawniony do określenia podatnikowi prawidłowej wysokości zwrotu podatku naliczonego lub nadwyżki podatku naliczonego nad należnym do odliczenia w następnych okresach rozliczeniowych. 
ści dodanej, czego wyrazem jest wprowadzenie systemu odliczeń podatku zapłaconego na poprzednich etapach obrotu ${ }^{47}$. Należy uznać, że zasada neutralności jest najpełniej zrealizowana, jeśli odliczenie następuje w możliwie najwcześniejszym okresie. W związku z tym organ podatkowy powinien przypisać podatek naliczony do okresu, w którym powstało prawo do odliczenia podatku naliczonego, tj. w stosunku do nabytych towarów lub usług powstał obowiązek podatkowy oraz podatnik otrzymał fakturę ${ }^{48}$. Jeżeli wskutek takiego działania okazałoby się, że za dany okres kwota podatku naliczonego przenosi kwotę podatku należnego, wówczas organ podatkowy powinien uwzględnić nadwyżkę w kolejnych okresach rozliczeniowych.

\section{Wnioski}

Na podstawie wskazanych wyżej rozważań można przedstawić kilka wniosków dotyczących charakteru zobowiązania podatkowego w podatku od towarów i usług. Bez wątpienia należy stwierdzić, że tę daninę publiczną cechuje otwarty podatkowy stan faktyczny. Kwota zobowiązania podatkowego jest bowiem ustalana jako różnica pomiędzy podatkiem należnym a naliczonym za konkretny okres rozliczeniowy. Otwarcie stanu faktycznego następuje z pierwszym dniem tego okresu, zaś jego zamknięcie wraz z upływem ostatniego dnia okresu.

W związku z tym należy stwierdzić, że zobowiązanie podatkowe w podatku od towarów i usług powstaje wraz z ostatnim dniem okresu rozliczeniowego. Tym samym za nietrafne trzeba uznać reprezentowane w nauce i orzecznictwie poglądy, że zobowiązanie podatkowe powstaje w dacie obowiązku podatkowego lub wraz z upływem terminu płatności podatku.

47 Wyroki Trybunału Sprawiedliwości Unii Europejskiej z 30 września 2010 r., C-392/09, pkt 34 i 35 oraz z 6 lipca 2006 r., C-439/04 i C-440/04, pkt 47 i 48, http://curia.europa.eu/ (dostęp: 29.01.2020 r.).

48 O ile oczywiście podatnik nie zrealizował tego uprawnienia w innym okresie rozliczeniowym, o którym stanowi art. 86 ust. 11 u.p.t.u. 
Konkretyzacja zobowiązania podatkowego na koniec okresu rozliczeniowego ma jednak charakter względny. Wiąże się to z przyjętą przez ustawodawcę wariantową konstrukcją podatkowego stanu faktycznego, w ramach której podatnik jest władny odliczyć podatek naliczony w trzech następujących po sobie okresach. Taki stan rzeczy można określić jako godny pochwały przejaw postulowanego w doktrynie uelastycznienia przepisów prawa podatkowego ${ }^{49}$.

Za dość oryginalne należy uznać rozwiązanie legislacyjne, zgodnie z którym formalny wybór podatkowy (decyzja o odliczeniu podatku naliczonego w konkretnym okresie rozliczeniowym) nie jest ograniczony terminem płatności podatku, ale co do zasady może zostać dokonany również po jego upływie. Wybór ten może być dokonany nawet podczas postępowania podatkowego, lecz nie później niż do chwili doręczenia decyzji określającej zobowiązanie podatkowe. W razie jej wydania organ powinien przypisać podatek naliczony do najwcześniejszego okresu, w którym prawo do odliczenia podatku naliczonego stało się prawnie dopuszczalne.

\section{Bibliografia:}

Bartosiewicz A., Komentarz do art. 99 ustawy o podatku od towarów i usług [w:] A. Bartosiewicz, VAT. Komentarz, Warszawa 2019, LEX/wersja elektroniczna.

Bącal A., Dominik D., Militz M., Ogiński P., Zasady dotyczq̨ce podatku od towarów i usług, „Przegląd Podatkowy” 2009, nr 11, s. 2-20.

Borszowski P., Determinanty elastyczności przepisów prawa podatkowego (na drodze do poprawy systemu podatkowego), „Annales Universitatis Mariae Curie-Skłodowska” 2016, nr 1, s. 183-189.

Borszowski P., Określenia nieostre i klauzule generalne w prawie podatkowym, Wolters Kluwer, Warszawa 2017.

49 P. Borszowski, Determinanty elastyczności przepisów prawa podatkowego (na drodze do poprawy systemu podatkowego), „Annales Universitatis Mariae Curie-Skłodowska” 2016, nr 1, s. 184. O zagadnieniu elastyczności przepisów prawa podatkowego zob. również P. Borszowski, Określenia nieostre i klauzule generalne w prawie podatkowym, Warszawa 2017. 
Borszowski P., Elementy stosunku prawnego zobowiqzania podatkowego, Kantor Wydawniczy Zakamycze, Kraków 2004.

Brzeziński B., Glosa do wyroku składu siedmiu sędziów Naczelnego Sq̨du Administracyjnego z dnia 25 sierpnia 2003 r. (FSA 1/03), „Przegląd Orzecznictwa Podatkowego" 2004, nr 3, s. 229-231.

Brzeziński B., Wstęp do nauki prawa podatkowego, TNOiK Dom Organizatora, Toruń 2001.

Brzeziński B., Zasady ogólne prawa podatkowego, „Toruński Rocznik Podatkowy” 2015, nr 1, s. 4-18.

Dzwonkowski H., Powstawanie i wymiar zobowiq̨ań podatkowych, Dom Wydawniczy ABC, Warszawa 2003.

Dzwonkowski H., Dzwonkowski M., Komentarz do art. 5 Ordynacji podatkowej [w:] H. Dzwonkowski (red.), Ordynacja podatkowa. Komentarz, Warszawa 2020, Legalis/wersja elektroniczna.

Etel L., Komentarz do art. 81 b Ordynacji podatkowej [w:] L. Etel (red.) Ordynacja podatkowa. Komentarz, Wolters Kluwer, Warszawa 2017.

Gomułowicz A., Klasyfikacja podatków [w:] A. Gomułowicz, J. Małecki, Podatki i prawo podatkowe, Warszawa 2006, LEX/wersja elektroniczna.

Kalinowski M., Kilka uwag dotyczq̨cych posługiwaniem się pojęciem obowiq̨zek podatkowy w projekcie nowej ordynacji podatkowej, „, Przegląd Orzecznictwa Podatkowego" 2018, nr 1, s. 12-16.

Kalinowski M., Poglq̨dy Otto Mayera na prawo i stosunki podatkowe, „Toruński Rocznik Podatkowy” 2015, nr 1, s. 19-27.

Korczyński I., Podatkowoprawny stan faktyczny [w:] B. Brzeziński (red.), Prawo podatkowe. Teoria. Instytucje. Funkcjonowanie, TNOiK Dom Organizatora, Toruń 2009.

Kosikowski C., Pojęcie i cechy ustawy podatkowej w Polsce [w:] C. Kosikowski, Ustawa podatkowa. Geneza, ewolucja i stan prawny; tworzenie; kontrola; wykładnia; wykonywanie, Warszawa 2006, LEX/wersja elektroniczna.

Kostecki S., Podatkowy stan faktyczny [w:] M. Mazurkiewicz (red.), Studia z zakresu polityki finansowej i prawa finansowego, Wydawnictwo Uniwersytetu Wrocławskiego, Wrocław 1992.

Mastalski R., Glosa do wyroku SN z dnia 18 maja 2001 r., III RN 95/00, „Orzecznictwo Sądów Polskich”, LEX/wersja elektroniczna.

Mastalski R., Obowiqzek podatkowy i zobowiqzanie podatkowe [w:] M. Weralski (red.), System instytucji prawno-finansowych PRL, Tom III, Instytucje budżetowe, Zakład Narodowy im. Ossolińskich, Wrocław 1985. 
Mastalski R., Prawo podatkowe, Wydawnictwo C.H. Beck, Warszawa 2014.

Mastalski R., Wprowadzenie do prawa podatkowego, Wydawnictwo C.H. Beck, Warszawa 1995.

Michalik T., Komentarz do art. 19a ustawy o podatku od towarów i usług [w:] Michalik T., VAT. Komentarz, Warszawa 2019, Legalis/wersja elektroniczna.

Mudrecki A., Opodatkowanie olejów smarowych w świetle orzecznictwa Naczelnego Sqdu Administracyjnego i Trybunału Sprawiedliwości Unii Europejskiej [w:] T. Nowak, P. Stanisławiszyn (red.), Prawo celne i podatek akcyzowy. Blaski i cienie dziesięciu lat członkostwa Polski w Unii Europejskiej, Warszawa 2016, LEX/wersja elektroniczna.

Niezgódka-Medek M., Komentarz do art. 5 Ordynacji podatkowej [w:] S. Babiarz, B. Dauter, R. Hauser, A. Kabat, M. Niezgódka-Medek, J. Rudowski, Ordynacja podatkowa. Komentarz, Wolters Kluwer, Warszawa 2019.

Popławski M., Komentarz do art. 5 Ordynacji podatkowej [w:] L. Etel (red.) Ordynacja podatkowa. Komentarz, Wolters Kluwer, Warszawa 2017.

Nita A., Porozumienia w prawie podatkowym. Horyzontalne metody determinacji powinności podatkowej, Wolters Kluwer, Warszawa 2014.

Nita A., Stosunek prawnopodatkowy. Obowiq̨zek podatkowy i zobowiqzzanie podatkowe, Kantor Wydawniczy Zakamycze, Kraków 1999.

Nita A., Uchylanie się od opodatkowania jako zjawisko z zakresu prawa karnego i podatkowego [w:] P. Kardas, T. Sroka, W. Wróbel (red.), Państwo prawa i prawo karne. Księga jubileuszowa Profesora Andrzeja Zolla. Tom I, Wolters Kluwer, Warszawa 2012.

Ofiarski Z., Prawo podatkowe, Wydawnictwo Prawnicze LexisNexis, Warszawa 2008.

Prejs E., Wartości konstytucyjne a prawo podatkowe w orzecznictwie Trybunału Konstytucyjnego [w:] B. Brzeziński (red.), Prawo podatkowe. Teoria. Instytucje. Funkcjonowanie, TNOiK, Toruń 2009.

Rosmarin S., Obowiqzek podatkowy. Studjum krytyczne w zakresie Ordynacji podatkowej, „Głos Prawa” 1935, nr 3-4, s. 163-178. 